\title{
TINJAUAN TEOLOGIS-ETIS TENTANG BISNIS MEMBUNGAKAN UANG
}

\author{
Dr. Malik, M.Th. \\ Sekolah Tinggi Teologi Injili Arastamar (SETIA) Jakarta \\ malikbambangan@sttsetia.ac.id
}

\begin{abstract}
ABSTRAK
Kebutuhan hidup manusia dalam segala aspek semakin hari semakin meningkat seiring dengan naiknya harga sembako yang semakin tinggi. Hal ini menuntut berbagai daya dan upaya yang dilakukan oleh manusia untuk memenuhi kebutuhan hidup tersebut agar tetap bertahan hidup. Namun karena himpitan ekonomi ini terlalu menekan hidup rakyat, maka banyak rakyat yang hidup miskin, melarat dan menderita. Banyaknya tuntutan hidup dalam kondisi ekonomi yang semakin carutmarut ini, memaksa pemerintah untuk segera turun tangan menyelesaikannya. Sebagai upaya pemerintah telah mengadakan KUD, UKM, KUR, BPR dan BKK. Program pemerintah dalam pengentasan kemiskinan seperti ini sedikit memberi solusi, namun sayangnya karena hal itu hanya berlaku bagi rakyat yang ekonominya menengah ke atas, untuk meningkatkan bisnis mereka. Sementara itu, untuk kelas ekonomi menengah ke bawah, semakin tertindas dalam kemiskinannya dan tidak diperhatikan. Hal ini seakan-akan menjadi pembiaran oleh pihak pemerintah yang membiarkan rakyat kecil, miskin hidup dalam kemelaratan. Sebagai dampak dari pembiaran ini maka muncullah kelompok yang ingin membantu sesamanya terbebas dari jerat kemiskinan itu. Kelompok ini memberikan pinjaman uang kepada siapa saja yang membutuhkan pinjaman disertai dengan bunganya. Kelompok ini sepertinya memberikan solusi yang cepat namun tidak tepat dalam memenuhi kebutuhan hidup. Karena pemberian pinjaman uang yang disertai dengan bunga serta waktu yang relatif singkat dalam pengembaliannya, hanya menguntungkan pihak pemberi pinjaman uang, sementara yang meminjam kembali terjebak dalam kubangan hutang bunga uang yang di pinjam untuk dibayar. Itulah sebabnya kelompok pelepas uang atau pemberi pinjaman uang ini disebut RENTENIR.
\end{abstract}

\section{Kata kunci: Teologis, Bisnis, Rentenir, Uang}

\section{ABSTRACT}

Needs of human life in all its aspects is increasingly rising along with rising food prices are higher. This requires a variety of resources and efforts made by humans to meet the needs of those living in order to survive. However, due to economic trouble is too much pressure on people's lives, so many people who live in poverty, destitute and suffering. The many demands of life in the economy continues to this profanity, forcing the government to immediately intervene to resolve it. As the government has been organized cooperatives, KUD, UKM, KUR, BPR and BKK. Government's poverty eradication programs like this a little give a solution, but unfortunately because it 
only applies to people whose economy is upper middle, to improve their business. Meanwhile, for the medium economic class, the oppressed in poverty and ignorance. It is as if the omission by the authorities who let the little people, the poor live in squalor. As a result of this omission then comes a group that wants to help others be free of the poverty trap. This group is lending money to anyone who needs a loan along with interest. This group seems to provide a quick solution but not exactly in meeting the needs of life. Because the lending of money, along with interest and a relatively short time in the return, the only benefit the money lenders, while the borrowing re stuck in a puddle of interest payable on the borrowed money to be paid. That is why the release of money or money lender is called loan sharks.

\section{Keywords: Theology, Bussiness, Moneylenders, Money}

\section{PENDAHULUAN}

Peminjaman uang dengan bunga adalah merupakan transaksi komersial yang marak dilakukan di era modern ini. Kegiatan pelepas uang atau rentenir ini semakin marak dilakukan secara khusus dipasar-pasar tradisional untuk para pedagang awalnya namun kini sudah merambah ke kalangan pegawai kelas menengah ke bawah. Kemasan yang yang rapi, tempat yang rapi dan bersistem telah dilegalkan oleh pemerintah selaku Bank Milik Pemerintah Daerah, namun bukan BPD. Instansi ini bergerak di bidang perkreditan dengan jaminan barang berdasarkan nilai jualnya, namun tidak sama dengan PEGADAIAN. Kalau PEGADAIAN PUNYA slogan; "Mengatasai masalah tanpa masalah." Akan tetapi di BPR, bukannya mengatasi masalah tanpa masalah, melainkan "menambah masalah." Hal ini mengingatkan penulis pada lagu Roma Irama dengan lirik lagu, 'gali lobang tutup lobang, pinjam uang bayar utang.' Di kabupaten Banyumas terdapat 24 kantor cabang BPR-BKK yang sangat memadai untuk terjadinya transaksi pinjaman berbunga. Suatu waktu penulis meminjam di BKK karena desakan pembayaran untuk ujian S2 jadi terpaksa meminjam walau bunganya cukup tinggi. Hal sama juga dialami pak OToy berdasarkan wawancara penulis dengan beliau, bahwa dia meminjam karena kebutuhan mendesak seperti bayar ujian. Namun berbeda lagi dengan bang Anto yang meminjam dengan alasan konsumtif. ${ }^{1}$ Kalau para pelaku rentenir lebih banyak beroperasi di pasar-pasar tradisional. Suatu hari penulis bertemu dengan salah anggota jemaat namanya 'Bunga' (bukan nama sebenarnya) yang sedang menjalankan aksinya di pinggir pasar tradisional Sumpiuh sebagai rentenir. Itu artinya bahwa praktik membungakan uang ini sudah sangat lazim, namun mengatsinya agak rumit. Ini merupakan pelarian pinjaman terakhir masyarakat ekonomi menengah ke bawah selain tetangga.

Begitu banyaknya orang yang membutuhkan pertolongan orang dalam hal pemenuhan kebutuhan hidup mereka. Pada saat seseorang berada dalam kesulitan ekonomi, maka jalan keluarnya adalah meminjam kepada orang lain. Entah dengan cara bagaimana yang penting mereka bisa mendapatkan pinjaman. Dalam keadaan seperti inilah muncul kelompok yang mau menolong tetapi dengan syarat

${ }^{1}$ Wawancara Penulis dengan Bang OToy dan bang Anto di Kelurahan Tanjung, Kecamatan Purwokwerto Selatan, Kab. Banyumas-Jawa Tengah; Tanggal 24 September 2017. 
pengembalian itu ada bunganya. Hal ini sangat menjanjijkan untuk dijadikan ladang bisnis bagi yang menjalankannya.

Suatu berita yang dilansir oleh Tribun news.com, Jakarta tanggal 28 April 2014 bahwa seorang yang dikenal sebagai (namanya Rohani) rentenir itu pekerjaannya adalah meminjamkan uang kepada warga sekitar dengan bunga sebesar 30 persen. Pembayarannya dibayarkan debitur dengan cara menyicil selama sekitar satu bulan. Misalnnya pinjaman uang Rp. 1 juta, maka bunganya dalam waktu satu bulan itu sebesar Rp. 300.000. Karena ibu Rohani ini meninggal dalam rumah kontrakannya sendiri, maka polisi mengadakan penyelidikan. Dalam penyelidikan ini, polisi menemukan buku tabungan di Bank Mandiri ibu Rohani tersebut sebesar Rp. 918 juta. ${ }^{2}$ Hal ini memberi pertanda bahwa seorang rentenir yang memberikan pinjaman bagi sesamanya dengan memberi bunga pinjaman tersebut mendapat untung yang sangat besar.

Bagaimana jika hal membungakan uang ini dihubungkan dengan Alkitab? Apakah tindakan memberikan pinjaman dengan membungakan uang tersebut diperbolehkan menurut Alkitab? Apakah orang Kristen boleh meminjam atau tidak? Apakah orang Kristen tidak boleh memberi pinjaman supaya tidak terjerat dalam riba atau membungakan uang? Lalu bagaimana dengan penerapan prinsip kasih sebagai orang Kristen? Inilah yang akan dibahas dalam tulisan ini untuk menjawab pertanyaan-pertanyaan di atas.

\section{METODE PENELITIAN}

Adapun dasar penelitian penulis adalah dengan menggunakan metode wawancara dan juga metode penelitian yang bersifat deskriptif melalui pengumpulan data-data untuk memberikan gambaran suatu konsep atau gejala dalam menjawab pertanyaan-pertanyaan sehubungan dengan status subyek penelitian pada saat ini. Peneliti membaca, mengerti dan merangkum undang-undang tentang peminjaman Uang berbunga dalam KUHP. Mengidentifikasi masalah peminjaman uang yang berbunga berdasarkan teks Keluaran 22:25. Dengan demikian akan memberikan rumusan berupa impilkasi bagi orang percaya masa kini.

\section{PEMBAHASAN}

\section{Membungakan Uang (Rentenir)}

Kata bunga dalam bahasa Ibrani disebut neshek, ְָשָׁה nashah dari kata naw-shaw yang artinya adalah bunga. Sedangkan uang dalam bahasa Ibrani disebut ๆọ keceph dari kata keh'-sef yang artinya adalah uang. Poerwadarminta, dikutip oleh Bambangan menyatakan bahwa, pengertian riba adalah hidup dengan membungakan uang; menghisap darah (membungakan dengan rente yang amat banyak); atau bunga uang. ${ }^{3}$ Sedangkan rentenir menurut Kamus Besar Bahasa Indonesia adalah orang yang mencari nafkah dengan membungakan uang. ${ }^{4}$ Kelompok pemberi pinjaman ini sering disebut dengan istilah Rentenir. Menurut Malik Darius Bambangan, ada

2 Sumber; http://www.tribunnews.com/metropolitan/2014/04/28/rohani-dikenal-sebagairentenir-dengan-bunga-30-persen. diakses tanggal 23-9-2014 oleh Malik.

3 W.J.S. Poerwadarminta, Kamus Besar Bahasa Indonesia, (Jakarta: Balai Pustaka, 1976),824, dikutip Malik Darius Bambangan dalam Mengelola Harta Kekayaan, (Yogyakarta:ANDI, 2013), 70.

4 Tim penyusun, Kamus Besar Bahasa Indonesia, (Jakarta: Balai Pustaka, 1990), 743 
kesamaan antara rentenir dengan riba. Jadi definisi makan riba atau menjadi rentenir adalah orang yang hidup dengan membungakan uang dan ini sama dengan sistem ijon yang mengambil kesempatan dalam kesempitan untuk meraup keuntungan sebesar-besarnya. ${ }^{5}$ Pengertian yang sama pula oleh Browining menyebut riba sebagai bunga yang dikenakan atas suatu pinjaman. ${ }^{6}$ Hal ini terpola dalam budaya sosial masyarakat Indonesia yang inginnya selalu instant. Dan sebagai akibatnya mereka melakukan itu walaupun dengan bunga yang tinggi. Selanjutnya Bambangan menyatakan bahwa Rentenir cerdik mengambil keuntungan dalam kesempitan orang yang susah yang membutuhkan keuangan dan memberikan pinjaman dengan bunga yang tinggi dan tidak wajar. ${ }^{7}$ Desakan kebutuhan hidup yang tidak terpenuhi menjadi lahan yang empuk bagi para rentenir ini menjalankan aksinya.

\section{Kegiatan para Rentenir}

Kegiatan daripada rentenir adalah sama halnya dengan mencuri milik orang lain secara halus. Dalam Katekismus Besar Martin Luther dituliskan, sebab mencuri sama saja dengan mendapatkan milik orang lain secara tidak sah. Singkatnya, yang termasuk mencuri ialah mengambil keuntungan dari sesama kita dalam urusan dagang apapun yang menimbulkan kerugian baginya. ${ }^{8}$ Itulah sebabnya Boice menyatakan bahwa, kita mencuri dengan salah mengelolah uang orang lain. ${ }^{9}$ Mungkin hal inilah yang disampaikan oleh Yesus dalam perumpamaan tentang talenta. Dimana ada seorang hamba yang salah menggunakan talenta itu karena tidak menjalankannya (lih. Mat. 25:14-30). Kesalahan daripada rentenir adalah mengambil uang orang lain dengan bunga. Memberikan pinjaman adalah hal yang mulia, demi menolong sesama dalam kesempitan, namun menarik bunga dari piutang tersebut adalah salah jika melampaui batas kewajaran. Browning dengan mengutip Matius 25:27 menuliskan bahwa, Perjanjian Baru menerima praktik perbankan (pinjam meminjam dengan bunga) ini sebagai hal yang lazim dalam hidup dan tidak bercela. ${ }^{10}$

Penulis sangat akrab dengan beberapa pelaku bisnis rentenir tersebut, baik itu sewaktu penulis masih kuliah di Jakarta maupun sekarang ini di Banyumas. Penulis dekat dengan mereka bukan karena penulis turut melakukannya atau setuju dengan perbuatan mereka, namun karena mereka itu adalah note bene orang Kristen juga dan sering ke Gereja. Tujuan pendekatan penulis adalah untuk merangkul mereka, namun sampai saat ini mereka masih tetap geluti. Prinsip bisnis mereka adalah yang penting ada persetujuan, kalau yang ingin meminjam tidak setuju dengan besaran bunga pinjaman tersebut, tidak ada paksaan. Namun mayoritas mereka yang meminjam itu setuju dengan ketentuan bunga tersebut. Jadi tidak ada yang salah di sini, yang salah itu kalau mereka tidak membayar utangnya.

Seorang rentenir dapat mengambil keuntungan dari orang yang meminjam uang kepadanya sekalipun dengan bunga yang besar. Rentenir adalah penghisap darah sesamanya homo homini lupus, lintah darat di mana ia hidup sama halnya dengan

5 Malik Darius Bambangan, Mengelola Harta Kekayaan, (Yogyakarta: ANDI, 2013), 71

${ }^{6}$ W.R.F. Browning, Kamus Alkitab, (Jakarta: BPK Gunung Mulia, 2012),385

7 Bambangan, Mengelola Harta, 71

${ }^{8}$ Anwar Tjen, Katekismus Besar Martin Luther, (Jakarta; BPK Gunung Mulia, 1996), 82 dalam Bambangan, Mengelola Harta Kekayaan, 71

${ }^{9}$ James Montgomery Boice, Dasar-Dasar Iman Kristen, (Surabaya: Momentum, 2011), 270

10 Browning, Kamus Alkitab, 385 
memeras sesamanya yang datang meminjam kepadanya. Itulah sebabnya Herlianto menyatakan, kekayaan itu ada karena menindas buruh, dagang yang curang (manipulasi) dan korupsi. ${ }^{11}$ Menjadi rentenir memang bisa menjadi kaya, akan tetapi bagi orang percaya kalau menyadari arti dan pentingnya kasih itu maka tidak akan ada lagi korban dari rentenir itu. Boleh meminjam uang kepada orang lain, dan boleh juga memberi pinjaman, namun ingat yang namanya pinjam itu berarti harus ada gantinya. Memang ada gantinya, namun pengembaliannya adalah sesuai dengan jumlah yang dipinjamkan sebelumnya. Eka Darmaputera menyatakan bahwa, laba, penumpukan dan pengembangan modal, sukses material dan sebagainya, tidak boleh menjadi tujuan akhir, hanya karena untuk mengejar harta dan mendapat kekayaan. ${ }^{12}$

Prinsip hidup daripada rentenir yaitu, kesempatan itu hanya datang sekali dan tidak dua kali. Tanpa peduli terhadap sesama, dalam keadaan terjepitpun rentenir tetap menjalankan aksinya. J. Sidlow Baxter dikutip Bambangan menyatakan, Orangorang kaya tidak mau pusing dengan keadaan masyarakat yang terjepit dan serba susah, mereka justru mengambil kesempatan untuk mengeruk keuntungan yang besar bagi diri sendiri.13 Memang orang bisa dengan cara demikian mendapatkan kekayaan, tetapi perlu diingat bahwa itu untuk berbelas kasih kepada orang-orang lemah (Ams. 19:17). Hidup dari bunga uang itu boleh, asal jangan melebihi dari apa yang sudah disepakati dengan orang yang meminjam. Transaksi pinjaman harus jelas, jangan ada kecenderungan di dalamnya tetapi harus fair dan adil. Hidup orang percaya haruslah mencerminkan kasih Kristus yang rela berkorban bagi sesama. Jadi mengasihi orang lain itu jangan menuntut balas sebab janji Bapa sendiri yang akan membalaskannya pada setiap pengikut-Nya (Mat.6:3-4). Dalam Firman Tuhan dilarang memberikan uang dan makanan kepada saudara dengan membungakannya (Im. 25:35-37; Ul. 23:19; Neh. 5:7).

\section{Dasar Hukum Perdata14}

Berbicara mengenai utang-piutang (pinjam meminjam) tersebut yang konon disertai dengan bunga adalah benar menurut hukum yang berlaku di Indonesia. Hal itu diatur dalam KUH Perdata pasal 1765-1769 yang merumuskan tentang peminjaman uang disertai dengan bunga. Dalam tatanan negara RI juga mengatur tentang bagaimana hidup bermasyarakat itu dilaksanakan. Aturan perundangundangan memberi irama gerak setiap warga negara sehingga berjalan menurut tata aturan yang berlaku dengan demikian etika normatif masih tetap berjalan. Dalam membahas tentang persoalan membungakan uang (rente?), hal itu telah ditetapkan dalam Undang-Undang KUH Perdata. Pasal 1765 KUHP, berbunyi Untuk peminjaman uang atau barang yang habis dalam pemakaian, diperbolehkan membuat syarat bahwa atas pinjaman itu akan dibayar bunga.

Kemudian dijamin lagi dengan munculnya pasal 1766 KUHP yang berbunyi, "Barangsiapa sudah menerima suatu pinjaman dan telah membayar bunga yang tidak

${ }^{11}$ Herlianto, Teologi Sukses, (Jakarta BPK Gunung Mulia, 1996),136, dalam Bambangan, Mengelola Harta, 72

12 Eka Darmaputera, Etika Sederhana; Bisnis, Ekonomi dan Penatalayanan, (Jakarta: BPK Gunung Mulia, 1995),12, lih. Juga, Bambangan, Mengelola Harta,104

13 J. Sidlow Baxter, Menggali Isi Alkitab I Kejadian-Ester, (Jakarta: YKBK/OMF, 1997), 468

${ }^{14}$ KITAB UNDANG-UNDANG HUKUM PERDATA, e-Book, (Burgerlijk Wetboek voor Indonesie) hlm. 320 diambil dari http://hukum.unsrat.ac.id/uu/kolonial_kuh_perdata.pdf, tgl. 23-9-2014, oleh Malik 
diperjanjikan dahulu, tidak dapat meminta kembali bunga itu dan juga tidak dapat mengurangkannya dan pinjaman pokok, kecuali jika bunga yang telah dibayar itu melampaui jumlah bunga yang ditetapkan dalam undang-undang; dalam hal ini uang kelebihan itu dapat diminta kembali atau dikurangkan dan pinjaman pokok. Pembayaran bunga yang tidak diperjanjikan tidak mewajibkan debitur untuk membayar bunga terus, tetapi bunga yang diperjanjikan wajib dibayar sampai pada saat pengembalian atau penitipan (konsinyasi) uang pinjaman pokok semuanya walaupun pengembalian atau penitipan uang pinjaman itu dilakukan tatkala sudah lewat waktu pelunasan menurut perjanjian."

Jadi pemerintah dalam hal ini memberikan kesempatan bagi siapa saja yang dapat memberikan pinjaman dengan bunga asalkan hal itu sesuai dengan perjanjian awal. Nilai pergerakan bisnis makin terbuka lebar dalam hal praktik membungankan uang kepada sipemimjam uang. Inilah kesempatan yang paling legal untuk memeras orang lain dengan cara yang halus namun akhirnya menikam dari belakang. Tidak peduli keterpurukan ekonomi separah apa dan bagaimana yang penting hal itu masih sesuai dengan undang-undang yang berlaku. Sebagai akibatnya perbedaan yang kaya dan yang miskin semakin terbuka lebar bagaikan kubur yang ternganga. Pemerintah seakan bermasa bodoh dengan praktik yang melanda rakyat ekonomi menengah kebawah.

Dalam KUHP, Pasal 1767, mengatur tentang dua bagian penetapan bunga, baik itu menurut UU maupun hanya melalui perjanjian yang penting secara tertulis. Sangat disayangkan karena dalam pasal ini memberi kelonggaran bagi rentenir untuk melipat gandakan bunga melampaui UU berdasarkan perjanjian. ${ }^{15}$ Demikianlah dilanjutkan dalam KUHP pasal 1768 bahwa, 'Jika pemberi pinjaman memperjanjikan bunga tanpa menentukan besarnya, maka penerima pinjaman wajib membayar bunga menurut undang-undang.' Inilah fenomena yang terjadi di bangsa ini. Nilai-nilai kehidupan seakan dapat ditukar atau dibeli dengan materi, karena kita ada di zaman materialism. Zaman yang mengukur segala sesuatu dengan materi.

Jadi dengan demikian pinjaman dengan membungakan uang tersebut sah hukumnya berlaku di Indonesia. Barangsiapa yang mau melakukan kegiatan tersebut tentunya tidak ada larangan untuk melakukannya asalkan masih sesuai dengan undang-undang yang berlaku. Lalu bagaimana dengan kekristenan itu sendiri? Apakah hal memberi pinjaman dengan membungakan uang dapat dibenarkan berdasarkan kebenaran Firman Tuhan? Apakah boleh memberikan pinjaman kepada orang lain dengan tidak membungakannya? Jika demikian apakah juga orang Kristen diperbolehkan berhutang? Hal inilah yang dibahas selanjutnya dalam tinjauan teologis berikut ini.

\section{PANDANGAN TEOLOGIS}

Musa mengingatkan orang Israel agar tidak mengambil bunga atau riba dari seseorang yang meminjam kepadanya. Dalam Keluaran 22:25 menyatakan, jika engkau meminjamkan uang kepada salah seorang dari umat-Ku, orang yang miskin di

15 KUHP, pasal 1767: Ada bunga menurut penetapan undang-undang, ada pula yang ditetapkan dalam perjanjian. Bunga menurut undang-undang ialah bunga yang ditentukan oleh undang-undang. Bunga yang ditetapkan dalam perjanjian boleh melampaui bunga menurut undang-undang dalam segala hal yang tidak dilarang undang-undang. Besarnya bunga yang ditetapkan dalam perjanjian harus dinyatakan secara tertulis. 
antaramu, maka jangalah engkau berlaku sebagai seorang penagih hutang terhadap dia: janganlah kamu bebankan bunga uang kepadanya. Kaiser menuliskan bahwa, dalam masa-masa modern, secara prinsip hutang diperlukan sebagai sarana untuk meningkatkan modal yang dipakai orang untuk bekerja. Jika seseorang tidak memiliki modal yang lebih besar, maka industri tertentu itu mungkin tak mampu mendatangkan pendapatan yang meningkat. Namun pada masa lalu, perhatian seperti itu tak sebesar yang terjadi pada masa-masa modern ini. Maka, pinjaman-pinjaman pada waktu itu hampir khusus untuk meringankan kemelaratan dan kelaparan yang hebat. ${ }^{16}$

Dalam hal ini jelas memberikan anjuran kepada setiap orang yang kaya agar bertindak kasih terhadap orang yang miskin, bukannya memeras mereka dengan memberi bunga uang pinjaman. Uang yang dipinjamkan tersebut hendaknya merupakan tindakan berbaik hati terhadap orang-orang yang sangat membutuhkannya.

Menarik bunga dalam kasus semacam itu, yakni dengan mengambil keuntungan dari kebutuhan orang lain, adalah bertentangan dengan norma atau etika Kristen berdasarkan Alkitab. Itulah sebabnya Allah melarang bangsa Israel untuk mengambil bunga atas uang yang dipinjamkan kepada mereka yang kekurangan dalam memenuhi kebutuhan hidup atau kebutuhan pokok mereka (Im. 25:25, 35, 39, 47).

Di sini dapat dilihat bagaimana tindakan preventif Allah terhadap pemerasan yang akan dilakukan oleh orang kaya terhadap orang miskin diantara orang Israel pada saat itu. Lalu bagaimana dengan Ulangan 23:20 yang memperbolehkan mengambil bunga kepada orang asing? Adapun maksud penjelasan dalam ayat $20 \mathrm{ini}$ adalah memberikan pinjaman uang dengan bunga yang wajar kepada orang yang bukan Israel dengan tujuan komersial (Ul. 23:20). Sayangnya, pemaknaan peminjaman uang dengan bunga saat ini telah bergeser, yakni boleh memberikan bunga atas setiap pinjaman entah itu wajar atau tidak wajar yang penting ada yang memberi pinjaman. Bahkan yang lebih tragis lagi karena adanya pinjaman bunga berbunga. Apakah ini manusiawi atau tidak, namun sebagian dari mereka berkata 'karena sudah ada persetujuan diantara kedua belah pihak, maka itulah yang berlaku, jangan ikut campur. ${ }^{17}$ Jika demikian tindakan rentenir dalam kasus ini merupakan pemaksaan secara halus kepada korbannya untuk meminjam supaya dapat bunga dari pinajaman tersebut. Tindakan seperti ini merupakan tindakan pencurian yang terselubung. Apakah pencurian itu? Pencurian adalah merupakan tindakan yang mengambil barang milik orang lain tanpa persetujuan atau dengan secara paksa. Boice menyatakan bahwa tidak dapat dipungkiri bahwa kita sering merampok dari orang-orang lain apa yang adalah hak mereka sehingga menjadi pencuri-pencuri dalam penilaian Allah. ${ }^{18}$

Dalam hal ini telah terjadi ketimpangan pada saat mengambil keputusan, dimana keputusan itu redaksinya hanya berasal dari salah satu pihak saja yakni

16 Walter C. Kaiser Jr., Ucapan-Ucapan Yang Sulit dalam Perjanjian Lama, (Malang: SAAT, 2007),

17 Fenomena ini memang sering terjadi di lapangan dialami oleh penulis selama dalam pelayanan ketika menghadapi kasus-kasus yang serupa. Namun ketika diadakan penelitian secara spesifik ternyata mayoritas diantara mereka mengakui terpaksa menyetujui karena terjebak dengan ketidaktahuan tentang pernak-pernik perbankan itu sendiri. Di sinilah letak kelemahan perbankan di tanah air. Sudah tahu kalau hal itu merugikan orang yang ekonominya lemah, tetapi malahan dibuatkan undang-undang.

18 Boice, Dasar-Dasar Iman Kristen, 271 
sipemberi pinjaman. Tindakan sipelepas uang (rentenir) ini kelihatannya menolong, namun sebenarnya memanfaatkan kesempatan kekurangan orang lain untuk mengambil untung dari bunganya. Siapa saja yang menjadi korban mereka, sehingga terjadi kasus seperti ini? Rupanya sasaran mereka adalah para buruh, karyawan, pedagang serta yang menjadi anggota koperasi turut menjadi korban penipuan terselubung ini. Musa menyampaikan kepada orang Israel demikian, 'Janganlah engkau mengambil bunga uang atau riba dari padanya, melainkan engkau harus takut akan Allahmu, supaya saudaramu dapat hidup di antaramu. Janganlah engkau memberi uangmu kepadanya dengan meminta bunga, juga makananmu janganlah kauberikan dengan meminta riba' (Im. 25:36-37).

Apabila saudaramu jatuh miskin, sehingga tidak sanggup bertahan di antaramu, maka engkau harus menyokong dia sebagai orang asing dan pendatang, supaya ia dapat hidup di antaramu. Janganlah engkau mengambil bunga uang atau riba dari padanya, melainkan engkau harus takut akan Allahmu, supaya saudaramu dapat hidup di antaramu. Janganlah engkau memberi uangmu kepadanya dengan meminta bunga, juga makananmu janganlah kauberikan dengan meminta riba (Im. 25:35-37).

Stedman dan Denny menyatakan mengenai kitab Imamat bahwa, kitab ini membahas hubungan-hubungan di dalam keluarga, di antara para sahabat, dan dengan masyarakat secara umum. Kitab ini secara tepat menunjukkan kepada kita jenis hubungan kasih yang diwujudkan Allah dalam semua bidang kehidupan ini. ${ }^{19}$ Yang dimaksudkan dengan saudaramu adalah sesama orang Israel. Pinjaman kepada kawan-kawan yang membutuhkan tidak boleh dibungakan. Justru orang yang membutuhkan pertolongan harus ditolong dengan diterima untuk tinggal diantara mereka serta menikmati hal-hak yang sama dengan orag asing atau pendatang yang sekalipun tidak bisa memiliki tanah sendiri, namun diizinkan untuk mengumpulkan harta dan hidup dengan nyaman sebagai orang bebas. ${ }^{20}$ Kehidupan pelepas uang dengan bunga yang tinggi adalah orang yang mengalami tekanan jiwa karena telah menekan sesamanya melalui perbuatannya. Tekanan jiwa di sini bukan berbentuk fisik, namun sebagai endingnya berakibat fatal kepada fisik manusia yang menjadi korbannya. Hari yang gembira adalah obat yang manjur, namun semangat yang patah mengeringkan tulang (Ams. 17:22). Inilah akibat yang diderita oleh orang yang terjerat utang yang banyak ditambah dengan bunga berbunga.

Begitu pentingnya pesan ini sehingga disampaikan oleh beberapa kali dalam Keluaran, Imamat dan Ulangan. Itu artinya bahwa orang Israel telah familiar dengan konsep membungakan uang. Hal ini mungkin terpola ketika mereka berada dalam masa perbudakan di Mesir atau bisa juga merupakan suatu tradisi bagi masyarakat yang hidup baik di Mesir, Kanaan bahkan bangsa-bangsa lain yang berada di sekitar mereka saat itu. Perintah atau larangan ini diulangi lagi oleh Musa dalam kitab Ulangan bahwa janganlah engkau membungakan suatu pinjaman kepada saudaramu, baik uang maupun bahan makanan atau apapun yang dapat dibungakan (Ul. 23:19). Menanggapi hal tersebut di atas, Maka Allah berfirman kepada bangsa Israel agar

${ }^{19}$ Ray C. Stedman \& James D. Denny, Petualangan Menjelajah Perjanjian Lama, (Jakarta: Duta Harapan Dunia, 2010), 107

${ }^{20}$ http://alkitab.sabda.org/passage.php?passage=im. 25:35-37\&tab=text, Terjemahan, Wycliffe, SABDA web. Yayasan Lembaga SABDA, copyright,@2005-2014. 
tidak memperlakukan umat-Nya dengan semena-mena, hanya karena mereka miskin. Kondisi sosial di Indonesia sangat kena dengan seruan ini, termasuk juga warga gereja yang sudah mulai menjaga jarak dengan sesamanya. Dengan demikian akan sangat tepat dengan apa yang disampaikan oleh Kaiser bahwa,

Alasan bagi pelarangan yang keras terhadap pengenaan riba adalah karena sudah terlalu banyak kejadian di Israel yang menggunakan metode ini untuk menghindar dari kaum miskin dan sesama warga mereka sendiri. Ulangan 23:20 mengatakan, dari orang asing boleh engkau memungut bunga. Nampaknya ini merupakan hal yang sama dengan riba untuk hutang bisnis atau investasi, yang juga diperbolehkan dalam Matius 25:27. Orang asing dikategorikan dalam warga asing, yang telah menetap diantara bangsa Israel. Namun bila hukum melindungi warga asing dengan hak-hak yang sama seperti yang diberikan kepada seorang Israel pribumi, kita boleh mengharapkan bahwa pelarangan yang sama terhadap hutang dengan riba kepada kaum miskin (lih. Imamat 25:35). ${ }^{21}$

Nampaknya Kaiser begitu jeli mencermati situasi dan konteks yang terjadi dalam teks Keluaran 22:25 ini sehingga memberikan kontribusi penafsiran yang sangat relevan. Kajian teologis perlu melihat latar belakang teks dan konteks secara benar dan tepat sehingga melahirkan penafsiran yang tepat dan benar pula. Orang yang miskin sangat membutuhkan pertolongan orang yang mampu menolong mereka. Kesempatan untuk menolong orang miskin ini diberikan kepada orang Israel. Maka jika dilihat dari sudut pandang etika praktikalnya akan sangat jelas dengan pemaparannya Kaiser demikian,

Apa yang telah mengubah pendapat dalam masa-masa modrn terhadap bentuk-bentuk yang sah untuk mengambil riba adalah persepsi yang telah berubah atas natur dan penggunaan uang. Perbedaan yang pertama, hutang pada masa kini kebanyakan dibutuhkan untuk berbagai tujuan yang berbeda. Pada masa itu hutang adalah masalah kebutuhan yang sungguh-sungguh sangat diperlukan yang akan memaksa orang masuk ke dalam posisi perlu meminjam. ${ }^{22}$

Selanjutnya dalam penjelasan mengenai utang piutang tersebut, Kaiser menjelaskan bahwa, dalam kasus-kasus ini, apa yang terhutang di antara sesama adalah belas kasihan. Mereka harus saling menolong, bukannya memanfaatkan kelemahan sesama sebagai kesempatan untuk memperoleh keuntungan secara cepat dan tidak sah. ${ }^{23}$ Pesan teologis dalam kitab Keluaran adalah berbicara mengenai rancangan penyelamatan Allah bagi umat-Nya Israel secara progresif. Menjalani rancangan Allah tersebut adalah tentu melibat manusia sebagi pesertanya yang memainkan peran dari Allah. Umat manusia sadar akan dirinya sebagai ciptaan Tuhan menjadi kunci untuk terhindar dari kesombongan. Sadar sebagai mahluk sosial berarti akan memberi ruang bebas untuk orang lain dapat agar dapat berguna bagi sesamanya.

${ }^{21}$ Kaiser, Ucapan yang Sulit, 81

22 Kaiser, Ucapan yang Sulit, 81

23 Kaiser, Ucapan yang Sulit, 81 
John Stott menyatakan, Alkitab tentu menganggap kerja sebagai proyek kemasyarakatan, yang dilakukan oleh masyarakat untuk masyarakat. Semua jenis kerja harus diliha, setidak-tidaknya hingga taraf tertentu, sebagai pelayanan terhadap kepentingan bersama. Prinsip ini membantu sekali dalam berdiskusi tentang makna atau tujuan-tujuan bisnis. ${ }^{24}$ Tantangannya sekarang adalah apakah para pelaku bisnis yang notabene orang Kristen itu mampu memilki wawasan sosial sehingga pengejaran akan keuntungan hanya merupakan salah satu tujuan disamping menolong sesama dan memelihara lingkungannya? ${ }^{25}$ Jika praktik membungakan uang dapat diterima oleh masyarakat setempat, maka menjadi tugas daripada pelepas uang (rentenir) tersebut untuk membangun suatu mutu hubungan yang baik dalam tatanan masyarakat dimanapun ia berada.

\section{HASIL}

Sebagai hasil dari pembahasan tersebut di atas, dapat mengimplikasikan kepada bahwa orang yang kaya yang sukses itu hendaknya memperhatikan sesamanya. Bisnis untuk menjadi sukses adalah tidak salah dalam iman Kristen jika hal itu dilakukan berdasarkan tindakan-tindakan yang etis dan alkitabiah. Yesus juga menyampaikan kepada para murid-Nya agar jangan menuntut balas akan perbuatan kasih mereka terhadap orang lain (Mat. 6:1-4). Beberapa hal yang menjadi implikasi bagi orang percaya berkaitan dengan pembahasan ini adalah sebagai berikut:

\section{Dampak kehidupan Sosial}

Rifai menyatakan bahwa, kehidupan sosial akan sangat dirasakan sekali oleh kaum marjinal yang hidup di perkotaan besar. Berkembangnya perkotaan dengan berbagai peradabannya telah membuat kota semakin jauh dari kerangka kepedualian sosial. ${ }^{26}$ Inilah dampak sosial yang terjadi dalam kehidupan masyarakat masa kini. Adanya perbedaan yang sangat jauh antara yang kaya dan miskin. Persoalan tentang kehidupan kaya dan miskin merupakan masalah yang selalu timbul dalam sejarah kehidupan manusia. Demikian Herlianto yang dikutip oleh Malik Darius Bambangan dalam Mengelola Harta Kekayaan. ${ }^{27}$

Kurangnya kepedulian sosial terhadap sesama telah melahirkan jurang pemisah antara satu dengan yang lain dalam kehidupan manusia. Rifai menjelaskan bahwa, penanaman nilai-nilai kepedulian sosial sejak kecil yang disertai dengan sikap empati sebagai perwujudan dan keberimanan seseorang terhadap Tuhan, juga harus disertai dengan sikap berkeadilan sosial. ${ }^{28}$ Pengertian keadilan sosial sebagaimana Rifai dalam mengutip Kristiayanto menyatakan bahwa menurut ajaran gereja keadilan sosial adalah kewajiban semua orang atau pihak yang berbuat adil satu terhadap

24 John Stott, Isu-Isu Global-Menantang Kepemimpinan Kristiani, (Jakarta: YKBK, 2000), 221

25 Daniel Ronda, Leadership Wisdom, (Bandung: Kalam Hidup, 2011), 84, mengutip E.G. Singgih, Reformasi dan Transformasi Pelayanan Gereja Menyongsong Abad ke-21, Yogyakarta:Kanasius, 1997), 89-106.

${ }^{26}$ Rifai, Yesus dan Kepedulian Sosial, (Solo: JURNAL ANTUSIAS, 2013), 49

${ }^{27}$ Herlianto, Teologi Sukses,130, dalam Bambangan, Mengelola Harta, 2.

28 Rifai, Yesus dan Kepedulian Sosial, 51. 
lainnya sesuai dengan Injil. ${ }^{29}$ Walaupun ada perbedaan pengertian keadilan sosial dengan perbuatan sosial, namun hal itu tidak akan mengurangi tanggung jawab kita sebagai orang percaya agar menolong orang lain. Dengan demikian dampak kehidupan orang percaya tidak akan bertindak pelit terhadap sesamanya, melainkan akan tetap berbelas kasih. Inilah kegiatan warga gereja yang keluar untuk memberitakan kasih Kristus itu yakni dengan pelayanan kasih terhadap sesama.

Gerrit Singgih menuliskan, kegiatan diakonia pada hakikatnya adalah kegiatan kasih dalam rangka menghargai orang lain sebagai manusia yang adalah gambar Allah. Kegiatan perekonomian yang baik adalah mendukung diakonia, sedangkan yang tidak baik adalah pada akhirnya menghapuskan diakonia, "everyone for himself/herself." ${ }^{30}$ Sebagai mahluk rohani sekaligus mahluk sosial, maka perlu kita perhatikan sesama kita. Jika kita berkesempatan untuk menolong mereka maka kita menolongnya. Suatu saat tanpa diminta jika kita ditimpa musibah pasti tetangga kitalah yang akan menolong kita lebih dulu. Inilah yang dikatakan pepatah bahwa tetangga adalah saudara yang paling dekat. Amsal berkata, 27:10 Jangan kautinggalkan temanmu dan teman ayahmu. Jangan datang di rumah saudaramu pada waktu engkau malang. Lebih baik tetangga yang dekat dari pada saudara yang jauh (Ams.27:10).

\section{Dampak Kehidupan Moral}

Adalah merupakan tanggung jawab moral setiap orang percaya untuk memperhatikan sesamanya. Perhatian terhadap sesama tidak melulu materi, namun bisa merupakan tindakan lain yang meringankan beban penderitaan sesama. Kaiser menjelaskan bahwa tentu saja, semua moralitas mengutuk riba uang yang terlampau tinggi. Amsal 28:8 memperingatkan lanjut Kaiser, bahwa orang yang memperbanyak hartanya dengan riba dan bunga uang, mengumpulkan itu untuk orang-orang yang mempunyai belas kasihan kepada orang-orang lemah. ${ }^{31}$ Hal ini memberi peringatan untuk tidak mengumpulkan harta dengan memberikan bunga terlalu tinggi dari ketentuan yang berlaku. Jika hal itu terjadi maka sebaiknya orang yang kaya tersebut dengan bunga uang itu mengumpulkannya untuk orang-orang yang kurang mampu. Ini merupakan shok teraphy yang diberikan kepada para rentenir agar jangan beritndak semena-mena dalam membungakan uangnya. Inilah tindakan yang benar sebagai orang percaya yakni sebagai orang benar dengan tidak memungut bunga uang atau mengambil riba (Yeh. 18:8, 13, 17; 22:12). ${ }^{32}$

Moralitas agama sebagai orang percaya mesti diperdalam untuk membentengi sikap arogansi serta acuh tak acuh kepada orang lain. Tuntutan iman kristiani merupakan panggilan Allah yang berproses bagi setiap orang percaya untuk menjadi perpanjangan hati dan tangan Allah yang penuh kasih itu kepada umat manusia. Inilah panggilan Allah bagi setiap orang percaya untuk tampil beda dengan memancarkan kasih Allah di tengah-tengah dunian ini. Memperhatikan orang miskin adalah suatu bukti kasih Allah yang terpancar dalam diri setiap orang percaya.

${ }^{29}$ A. Eddy Kristiyanto, Spiritual Sosial:Suatu Kajian Kontekstual (Yogyakarta: Kanasius, 2010) hlm. 53 dalam Yesus dan Kepedulian Sosial, oleh Rifai (Solo: Jurnal ANTUSIAS, 2013) hlm. 51.

30 Emanuel Gerrit Singgih, Iman dan Politik Dalam Era Reformasi di Indonesia, (Jakarta: BPK Gunung Mulia, 2004) hlm. 145

${ }^{31}$ Kaiser, Ucapan yang Sulit, 81

32 Kaiser, Ucapan yang Sulit, 81 
Perbuatan kebajikan merupakan nilai tambah bagi orang Kristen karena ini merupakan pengejahwantahan kasih itu kepada sesama walaupun tidak seiman. Alvin Jeremiah menuliskan bahwa sejarah kemurahan orang Kristen memperlihatkan tentang bagaimana praktik kemurahan itu terhadap mereka yang paling kecil selalu merupakan kebajikan yang membedakan kekristenan dari agama lain. ${ }^{33}$

Dalam pandangan moral iman Kristen melihat perkembangan ekonomi bahwa telah terjadi pergeseran pada pola pikir umat manusia. Kalau dalam kehidupan orang Israel pada zaman PL itu masih boleh memberikan pinjaman kepada sesama yang miskin, maka sekarang mungkin sudah berbeda. Yang miskin akan semakin miskin dan yang kaya akan semakin bertambah kaya. Sama seperti penuturan Budiman menyatakan, satu hal yang pasti ialah bahwa sejak revolusi industri dan modernisasi tekhnologi merambah Eropa dan kemudian hampir seluruh belahan bumi, kita menyaksikan bahwa aspek religious tidak lagi memiliki tempat dalam perkembangan ekonomi. ${ }^{34}$ Itu artinya bahwa perkembangan zaman ini tidak lagi mempedulikan agama, namun lebih condong kepada materialisme. Bagaimana orang percaya memandang harta yang semuanya diukur dengan uang? Budiman dalam mengutip pendapat sekular Aristoteles yang tahu jika uang sudah menjadi segala-galanya, maka kita akan jatuh pada pola hidup yang 'tidak berbudi' (unvirtuous). Uang adalah hanya alat tukar menukar di dalam sistem ekonomi. Ada banyak aspek kehidupan lainnya yang jauh lebih penting, seperti kualitas moral, yang harus kita kejar dan kita tempatkan di atas harta benda. ${ }^{35}$ Jika Aristoles yang sekular saja tahu menempatkan uang itu di bawah hal-hal yang lebih berguna seperti moral, lalu pertanyaan bagi moralitas orang Kristen akan seperti apa terhadap kebendaan yakni uang.

\section{Dampak Kehidupan Rohani}

Untuk melihat tindakan orang Kristen dalam hal mengelola keuangannya, maka pengelolaan tersebut hendaknya senantiasa bercermin pada Alkitab. Dengan demikian tindakan untuk membungkan uang sebagai piutang kepada sesama tidak akan menyeret kita untuk melakukan tindakan pemerasan secara terselubung. Bambangan menyatakan, bahwa mendapatkan kekayaan dengan cara seperti menipu, korupsi, pemerasan melalui kekuasaan, dan makan riba atau rentenir adalah hal yang bertentangan dengan Firman Tuhan. ${ }^{36}$ Mendapatkan harta benda dengan cara yang halal merupakan tindakan yang mengandalkan Tuhan melalui kerja dan doanya. Budiman menyatakan bahwa, kita bekerja, memakai dan memberi dengan sukacita karena kita tahu semuanya itu datangnya dari Tuhan. Tetapi waktu hati kita terpaut pada Mammon, mata hati kita menjadi gelap, kita diikat oleh harta benda duniawi dan dengan mudah jatuh dalam berbagai dosa: serakah, tidak jujur, iri hati, dan sebagainya. ${ }^{37}$

33 Alvin Jeremiah, Kemurahan Terhadap Pekerja Rumah Tangga: Praktik Spiritual Bagi Para Majikan Kristen, dalam VERITAS, JURNAL TEOLOGI DAN PELAYANAN, Volume 10 Nomor 2 Oktober 2009 (Malang: SAAT, 2009), 39.

${ }^{34}$ Kalvin S. Budiman, Calvin dan Lima Pilar Institusi Sosial, dalam VERITAS, JURNAL TEOLOGI DAN PELAYANAN, Volume 10 Nomor 2 Oktober 2009 (Malang: SAAT, 2009)hlm. 199

35 Budiman, Calvin dan Lima Pilar Institusi Sosial, 200.

36 Bambangan, Mengelola Harta, 73

37 Budiman, Calvin dan Lima Pilar Institusi Sosial, 201, dengan mengutip A Harmony of the Gospel, 1.217.-219 

bahwa,

Sejalan dengan itu Th. Van den End yang dikutip Bambangan menjelaskan

Allah tidak hanya melarang pencurian (a) dan perampasan (b) yang dihukum oleh pemerintah. Segala tipu daya yang dirancang untuk memperoleh milik sesama kita manusia juga Dia namakan pencurian (c) apakah dilakukan dengan kekerasan atau dengan berbuat pura-pura adil, ataupun dengan timbangan, ukuran, takaran, barang-barang (d), mata uang palsu, dengan makan riba (e) atau dengan cara apapun yang dilarang oleh Allah. Selain itu juga segala sesuatu sifat kikir (f), dan segala pemborosan serta pemakaian dengan sia-sia atas pemberian-pemberian-Nya $(\mathrm{g})$. $^{38}$

Alkitab memberikan pedoman bagi orang percaya untuk melangkah menurut aturan Allah bagi umat-Nya. Jika di atas telah dipaparkan mengenai bagaimana dengan hidup yang membungakan uang serta makan riba dari sesamanya. Demi mencegah terjadinya praktik rentenir dan makan riba, maka orang percaya hendaknya memakai prinsip kasih sebagaimana tertulis dalam Alkitab. Kasih kepada Tuhan dan kasih kepada sesama manusia (Kel. 20:1-17; Mat. 22:37-40). Bagi orang Kristen yang diberkati Allah dengan materi atau uang yang lebih hendaknya tidak menutup mata dan hati serta rumahnya bagi orang yang meminta tolong kepadanya. Tissa Balasuriya menyatakan, Pesan Kristus berintikan kasih sebagai kebajikan utama, motivasi dan isinya. Kasih itu harus aktif, efektif, kreatif. Kasih ini menjembatani kesenjangan, berupaya menyatukan, membangun solidaritas dan persatuan. ${ }^{39}$ Demikian Amsal 3:27 menganjurkan agar tidak menahan kebaikan kepada orang lain yang berhak menerimanya. Frasa 'jangan' dalam Perjanjian Lama adalah dari kata Ibrani yakni lo yang artinya tidak boleh sama sekali. Jadi sebagai orang yang kaya tidak boleh menahan untuk memberi kepada orang yang meminta kepadanya.

Kehidupan yang hanya mementingkan diri sendiri adalah suatu tindakan yang tidak manusiawi dan dikutuk Tuhan. Di atas telah dibahas bagaimana orang yang kaya itu harus menolong sesamanya yang miskin. Bukan hanya itu, karena Allah juga melarang mereka untuk menarik bunga dari uang yang mereka pinjamkan kepada orang miskin tersebut. Inilah yang seharusnya menjadi perhatian orang percaya masa kini. Orang yang hanya mencari untung, namun melupakan tanggung jawabnya sebagai orang percaya, hendaknya segera sadar dan segera bertindak. Eka Darmaputera dikutip Bambangan menuliskan,

Tujuan mencari laba sekali lagi tidaklah salah. Tetapi tujuan tersebut (yang nota bene, bukan tujuan akhir) haruslah dilakukan dengan cara-cara yang tidak melanggar harkat serta martabat manusia sebagai citra Allah, bahkan seharusnyalah laba yang diperoleh itu difungsikan untuk meningkatkan harkat dan martabat manusia, sesuai dengan tujuan yang lebih agung dan halus dari bisnis itu sendiri. ${ }^{40}$ Ronda menuliskan bahwa, setiap pelaku bisnis pasti mencari untung dan semua orang pasti mengatahui hal itu. Dengan kata lain, tidak mungkin sebuah bisnis dapat berjalan bila tidak ada keuntungannya. Selanjutnya Ronda menjelaskan, keuntungan itu hendaknya bukan dijadikan satu-satunya tujuan dalam praktik bisnis sebab, bila demikian, seseorang

38 Th. Van den End, Enam Belas Dasar Calvinisme tentang Katekismus Hidelberg (Jakarta: BPK.GM, 2001), 229, dalam Bambangan, Mengelola Harta, 74

39 Tissa Balasuriya, Teologi Siarah, (Jakarta: BPK Gunung Mulia, 2011), 179

40 Eka Darmaputera, Op.cit., hlm. 14., dalam Bambangan, Mengelola Harta,72 
akan berupaya menghalalkan segala cara untuk mencapai untung. Ingatlah bahwa setiap perilaku orang percaya itu ada di bawah terang Kristus. ${ }^{41}$ Itu artinya bahwa keuntungan dalam dunia bisnis merupakan tujuan usaha para pebisnis, namun bagi setiap orang percaya selalu mengutamakan Tuhan dalam hidup.

Menggunakan uang untuk mendukung pekerjaan Tuhan adalah suatu tindakan positif dari langkah kongkrit seorang yang takut akan Tuhan. Mendukung pekerjaan Tuhan bagi orang percaya yang kaya, hendaknya menjadi dasar motivasi untuk mensyukuri berkat dan kasih setia Tuhan dalam hidup ini. Ruth F. Selan mengatakan, pemberian kepada Allah adalah suatu perwujudan ucapan terima kasih kepada-Nya dan sebagai suatu kesempatan dan hak istimewa untuk ambil bagian dalam kelangsungan pekerjaan Tuhan, untuk merebut jiwa dari tangan Iblis kepada tangan Tuhan. ${ }^{42}$ Kepemilikan uang yang banyak hendaknya dikelola dengan rasa syukur dan takut akan Tuhan. Menolong sesama manusia merupakan tanggung jawab orang percaya namun tidak membebaskannya dari tanggung jawabnya untuk tetap mendukung pekerjaan Tuhan.

Sebagai orang yang percaya kepada Tuhan sumber berkat, hendaknya merasa cukup karena Allah yang tetap meberkatinya. Tindakan menggandakan uang dengan secara tidak wajar adalah merupakan tindakan kriminal. Oleh sebab itu, hidup yang mengutamakan Tuhan akan menghindarkan orang percaya dari sikap hidup cinta uang. Cinta uang adalah akar dari segala kejahatan (I Tim. 6:10). Untuk menghindari jebakan pinjaman berbunga maka orang percaya, hendaknya rajin bekerja supaya mencukupi segala kebutuhan hidupnya. Demikian juga dengan yang sudah memiliki uang agar merasa cukup dengan bersyukur kepada Tuhan. Hal ini akan menghindarkan orang percaya dari tindakan menjadi rentenir (Ibr. 13:5). Bambangan menyatakan, kekayaan materi yang disertai dengan rasa puas serta syukur yang melimpah akan menjadi basic yang kuat dan ampuh untuk pertahanan iman yang kokoh dan tangguh. ${ }^{43}$

\section{KESIMPULAN}

Di akhir daripada pembahasan ini, penulis akan memberikan kesimpulan sekaligus menjadi penutup dalam tulisan ini. Bahwa Alkitab sebagai dasar dan pedoman hidup orang percaya adalah mutlak untuk dilakukan tanpa ada tawar menawar. Sifat mutlak Alkitab untuk diberlakukan dalam kehidupan orang percaya bahkan setiap manusiapun tidak dapat digeser atau dipengaruhi oleh kondisi apapun. Alkitab yang merupakan pondasi kehidupan manusia menjadi ciri khas bukan hanya sebagai pegangan saja, melainkan sebagai aturan atau norma hidup manusia untuk dilakukan. Dengan demikian Alkitab akan menjadi panduan dalam hidup orang percaya untuk bertindak kasih terhadap sesama dan bukan hanya untuk diri sendiri. Sikap egois adalah suatu motif atau tindakan yang dilakukan untuk menguntungkan diri sendiri dan merugikan orang lain. Itulah pengertian dari kata egois bukan hanya menguntungkan diri sendiri, namun sebaliknya merugikan orang lain.

Bisnis dalam dunia sekular menjadikan etika moral sebagai suatu standar yang relatif dan bukan merupakan suatu norma yang mutlak sebagaimana telah dituliskan dalam Alkitab. Etika Kristen bertitik tolak dari penyataan Allah sebagaimana

${ }^{41}$ Ronda, Leadership Wisdom, 83

42 Ruth F. Selan, Menggali Keuangan Gereja (Bandung: Kalam Hidup, 1995) hlm.22

43 Bambangan, Mengelola Harta, 90 
dinyatakan dalam Alkitab. Alkitab menjadi penentu, bersifat mutlak dengan berdasarkan akan kehendak Allah yang memegang kendali serta segala kuasa di dunia ini. Hanya kepada Dia sajalah semua umat manusia di dunia ini mempertanggung jawabkan segala perbuatannya, karena Dialah kebenaran sejati itu. Dialah kebajikan itu yang oleh manusia dapat berbuat kebajikan yakni kepada Allah dan sesama.

Orang percaya sangat dituntut untuk memberikan pinjaman kepada siapapun tanpa kecuali sebagaimana di katakan juga dalam Amsal 3:27-28, 'Janganlah menahan kebaikan dari pada orang-orang yang berhak menerimanya, padahal engkau mampu melakukannya. Janganlah engkau berkata kepada sesamamu: "Pergilah dan kembalilah, besok akan kuberi," sedangkan yang diminta ada padamu.

Mengenai pemberian bunga atas pinjaman, pada dasarnya Alkitab mengatakan tidak boleh berdasarkan Keluaran 22:25, Imamat 25:36-37. Seharusnya orang percaya menyokong saudaranya agar tetap bertahan hidup sebagaimana layaknya umat pilihan hidup di dunia ini (Im. 25:35). Pemberian orang percaya kepada orang lain, hendaknya jangan menuntut balas. Boleh mengambil pengembaliannya jika ada persetujuan untuk dikembalikan, namun tidak disertai bunganya walaupun terlambat mengembalikannya.

Untuk orang percaya sedapat mungkin jangan sampai berhutang, apalagi hanya untuk hal-hal yang konsumtif. Kalau terpaksa berhutang karena kebutuhan yang mendesak dan penting, maka bayarlah hutangmu itu tepat pada waktunya, jangan menundanya, apalagi berusaha untuk tidak membayarnya, itu tidak boleh.

Untuk pelayan Tuhan tetap dalam proporsinya sebagai pelayan Tuhan dan menjadi contoh bagi jemaatnya. Kalau terpaksa membeli secara kredit karena tuntutan pelayanan, boleh asalkan tetap mengatur pengelolaan uangnya dengan benar dan tepat, jangan sampai besar pasak daripada tiang. Pelayan Tuhan jangan meminjam uang hanya karena untuk kebutuhan bisnisnya yang pada akhirnya tidak dapat dibayarkan. Jika ada hamba Tuhan yang jatuh bangkrut karena bisnis mengakibatkan tidak bisa lagi membayar hutangnya, maka lebih baik untuk sementara dia mengundurkan diri jadi pelayan Tuhan. Hal ini demi menjaga nama baik jemaat Kristen supaya nama Tuhan tetap dipermuliakan. Bila sudah membayar dan memiliki kerinduan lagi melalui panggilan Allah baginya untuk melayani Tuhan kembali, silakan. Tuhan memberkati. 


\section{KEPUSTAKAAN}

A. Buku

ALKITAB, (Jakarta: LAI TB, 2004)

Balasuriya, Tissa., Teologi Siarah, (Jakarta: BPK Gunung Mulia, 2011)

Bambangan, Malik Darius., Mengelola Harta Kekayaan, (Yogyakarta: ANDI, 2013)

Baxter, J. Sidlow., Menggali Isi Alkitab I Kejadian-Ester, (Jakarta: YKBK/OMF, 1997)

Boice, James Montgomery., Dasar-Dasar Iman Kristen, (Surabaya: Momentum, 2011)

Browning, W.R.F., Kamus Alkitab, (Jakarta: BPK Gunung Mulia, 2012)

Budiman, Kalvin S., Calvin dan Lima Pilar Institusi Sosial, dalam VERITAS, JURNAL TEOLOGI DAN PELAYANAN, Volume 10 Nomor 2 Oktober 2009 (Malang: SAAT, 2009)

Darmaputera, Eka., Etika Sederhana; Bisnis, Ekonomi dan Penatalayanan, (Jakarta: BPK Gunung Mulia, 1995)

End, Th. Van den., Enam Belas Dasar Calvinisme tentang Katekismus Hidelberg (Jakarta: BPK.GM, 2001)

Herlianto, Teologi Sukses, (Jakarta BPK Gunung Mulia, 1996)

Jeremiah, Alvin., Kemurahan Terhadap Pekerja Rumah Tangga: Praktik Spiritual Bagi pRa Majikan Kristen, dalam VERITAS, JURNAL TEOLOGI DAN PELAYANAN, Volume 10 Nomor 2 Oktober 2009 (Malang: SAAT, 2009) hlm. 39.

Kaiser Jr, Walter C., Ucapan-Ucapan Yang Sulit dalam Perjanjian Lama, (Malang: SAAT, 2007)

Kristiyanto, A. Eddy., Spiritual Sosial:Suatu Kajian Kontekstual (Yogyakarta: Kanasius, 2010)

Poerwadarminta, W.J.S., Kamus Besar Bahasa Indonesia, (Jakarta: Balai Pustaka, 1976)

Rifai, Yesus dan Kepedulian Sosial, (Solo: JURNAL ANTUSIAS, 2013)

Ronda, Daniel., Leadership Wisdom, (Bandung: Kalam Hidup, 2011)

Selan, Ruth F., Menggali Keuangan Gereja (Bandung: Kalam Hidup, 1995)

Singgih, E.Gerrit., Reformasi dan Transformasi Pelayanan Gereja Menyongsong Abad ke-21, Yogyakarta:Kanasius, 1997). 
Iman dan Politik Dalam Era Reformasi di Indonesia, (Jakarta: BPK Gunung Mulia, 2004) hlm. 145

Stedman, Ray C., \& Denny, James D., Petualangan Menjelajah Perjanjian Lama, (Jakarta: Duta Harapan Dunia, 2010)

Stott, John., Isu-Isu Global-Menantang Kepemimpinan Kristiani, (Jakarta: YKBK, 2000) hlm. 221

Tim penyusun, Kamus Besar Bahasa Indonesia, (Jakarta: Balai Pustaka, 1990)

Tjen, Anwar., Katekismus Besar Martin Luther, (Jakarta; BPK Gunung Mulia, 1996)

\section{B. Wawancara}

Wawancara Penulis dengan Bang Toy di Kelurahan Tanjung, Kecamatan Purwokwerto Selatan, Kab. Banyumas-Jawa Tengah; Tanggal 24 September 2017.

\section{Internet}

Sumber; http://www.tribunnews.com/metropolitan/2014/04/28/rohani-dikenalsebagai-rentenir-dengan-bunga-30-persen. diakses tanggal 23-9-2014 oleh Malik.

KITAB UNDANG-UNDANG HUKUM PERDATA, e-Book, (Burgerlijk Wetboek voor Indonesie) hlm. 320 diambil dari

http://hukum.unsrat.ac.id/uu/kolonial kuh perdata.pdf tgl. 23-9-2014, oleh Malik

http://alkitab.sabda.org/passage.php?passage=im. 25:35-37\&tab=text, Terjemahan, Wycliffe, SABDA web. Yayasan Lembaga SABDA, copyright,@2005-2014. 